\title{
A High-Performance 75 W Direct Ammonia Fuel Cells Stack
}

\author{
Teng Wang, Yun Zhao*, Brian P. Setzler, Reza Abbasi, Shimshon Gottesfeld and Yushan \\ Yan \\ Department of Chemical and Biomolecular Engineering, Centre for Catalytic Science and Technology \\ University of Delaware, Newark, DE 19716
}

\begin{abstract}
Ammonia can be directly used as fuel to generate electric energy in a low-temperature direct ammonia fuel cell (DAFC), making the DAFC an attractive option for zero-emission transportation. However, with a high-performance and durable DAFC still to be demonstrated, and with the remaining need to identify a suitable first market, the introduction of this technology has been delayed so far. Here, we report a high-performance DAFC stack enabled by a hydrophobic spinel cathode, which achieves the best combination of performance and durability reported to date. Peak power density of $410 \mathrm{~mW} \mathrm{~cm}^{-2}$ and

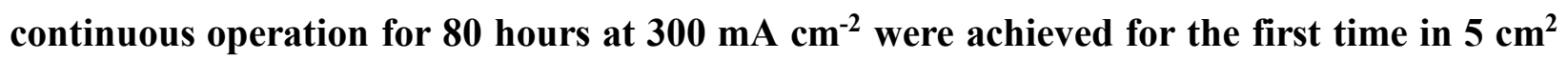
DAFCs, and then successfully scaled up to $50 \mathrm{~cm}^{2}$. Five such cells were assembled into a 75 W DAFC stack using graphite bipolar plates, demonstrating stack performance at the level expected from the single cell tests. The best combination of performance and durability for the single cell and, particularly, the demonstration of the world's first DAFC bipolar stack, constitute significant milestones in the development of DAFC technology. We also performed an in-depth techno-economic analysis of a $2 \mathrm{~kW}, 10 \mathrm{kWh}$ DAFC system serving as power source for drones. Based on the DAFC performance demonstrated by us to date, such system can be a competitive power source over hydrogen fuel cells and Li-ion batteries.

*Corresponding authors: e-mail: yzhao@udel.edu
\end{abstract}


Decarbonization of various sectors of the economy has become a major target, particularly so in the case of the transportation sector ${ }^{1-3}$. At the same time, ammonia has been gaining recognition as alternative fuel of significant potential for decarbonization of that sector. This recognition is based on the fuel's high energy density, large-scale global production, extensive existing infrastructure, and low cost per unit energy $y^{4-11}$. The recent attention to ammonia/air fuel cell power sources, is explained by this rising interest in ammonia as a non-carbon, alternative fuel for transportation $^{12-26}$. Low-temperature direct ammonia fuel cell (DAFC) has two important features of low temperature operation and direct use of the fuel stored on board as the anode feed stream. The importance of these two characteristics has been demonstrated by the successful commercialization of proton exchange membrane fuel cells (PEMFCs) as power sources for vehicles. The power system simplicity and the absence of high temperature fuel processing upstream the stack, are common to fuel cells with the direct $\mathrm{H}_{2}$ and $\mathrm{NH}_{3}$.

The optimum temperature for the operation of the DAFCs is $\sim 100^{\circ} \mathrm{C}$-- a compromise between (i) the need of higher cell temperature for enhancing the rate of the sluggish ammonia oxidation reaction (AOR) and, (ii) the upper limit of cell temperature defined by the demands of thermal stability for all cell components. As shown by us before, ${ }^{6,12,13,16,27,28}$, the operation of the DAFC near $100^{\circ} \mathrm{C}$ addresses to significant degree the power density demand, while leaving the door open for the use of ionic membranes -- the electrolyte of choice for low temperature fuel cells over the last 60 years. Indeed, the significant advances reported in recent years in performance and longevity of the DAFCs, were enabled by the progress in the development of hydroxide exchange membranes (HEMs) of high conductivity, and improved chemical and mechanical stability ${ }^{29}$. Such HEMs are a critical requirement for the development of polymer electrolyte DAFCs, as the 
proton conducting ionomers used for hydrogen fuel cells are deactivated by even ppm levels of ammonia, converting the protons in the ionomer to ammonium cations ${ }^{30}$.

With the quality of HEMs improving significantly, more recent DAFC R\&D efforts have targeted electrocatalysts of higher activity, and cell structures and operation conditions that secure an optimized distribution of an aqueous component across the cell thickness dimension. The anode catalysts identified to date as most active in the AOR at cell temperature below $120^{\circ} \mathrm{C}$, are based on Pt and Ir, in the form of either a binary alloy or the mixtures of Pt and Ir components. The limited catalytic activity of even these most active catalysts and the limited useful range of anode overpotentials available for the AOR at $\mathrm{Pt}$ and/or Ir catalysts, explain the requirement of cell operation at $\sim 100^{\circ} \mathrm{C}$ as the condition for reaching high peak power densities ${ }^{32}$. The choice of a cathode catalyst for the DAFC has been directed by (i) the desire to avoid use of any platinum group metal (PGM) beyond the high loadings of such catalysts required to date in anode and, (ii) a minimal effect of any contact with ammonia on the catalyst oxygen reduction reaction (ORR) activity. The latter directive stems from the recognition that some crossover of aqueous ammonia into the cathode is existing in DAFCs used to date. Coupling with ammonia crossover, our previous work further shows that the cathode of DAFCs is subjected to severe flooding due to high water concentration gradient from anode to cathode and high water permeability of $\mathrm{HEMs}^{27}$. As such, an ideal cathode is a cathode with an ORR catalyst that is highly tolerant to ammonia and highly resistant to flooding, allowing for the best combination of cell performance and durability.

Because a single cell cannot produce enough power output for transportation application, there is a crucial need to develop a DAFC stack consisting of a number of individual cells that can be ultimately built into a system. In addition to high-performance single DAFC requiring advanced materials and optimized operating conditions, the rational design for DAFC stacks is also an 
important factor to attain a high-performance DAFC stack. The bipolar plate design is critical because it is the key component in bipolar fuel cell stacks ${ }^{33-36}$. As for the bipolar plate's material selection, the most popular materials are metals and graphite composites ${ }^{37,38}$. Graphite offers low interfacial contact resistance and high resistance to corrosion by ammonia and potassium hydroxide. Still, some commonly used resins in composite graphite plates have insufficient chemical resistance, including vinyl ester and acrylic resins. A commercially available graphitepolypropylene composite bipolar plate was chosen to provide the necessary chemical resistance. Shunt current is also a particularly acute concern in DAFC stacks with graphite bipolar plates because strong base electrolyte, which is usually added into ammonia fuel for acquiring high cell performance, circulates through the anode side and leads to potential corrosion of graphite bipolar plates. Thus, minimizing the harmful effects of shunt current is essential for the designers of DAFC stacks. Also, compression load plays an important role in the performance of the stacks in a complex manner ${ }^{39-41}$.

Ultimately, a system including all necessary components will be needed to operate a DAFC stack to fulfill the practical application. From a commercialization perspective, the promising firstmarket which is the best fit for DAFCs is drones (unmanned aerial vehicles), particularly for agricultural use. In this industry, drones are commonly equipped for aerial photography, hyperspectral surveying, or nutrient/pesticide delivery. The majority of these businesses' emphasis is on taking heavy loads beyond the visual line of sight due to the large land areas they need to cover. Battery-powered drones are popular for the current drone market, but one of the biggest obstacles is their short flight time under 40 minutes $^{42}$. Hydrogen-powered drones are beginning to enter the plug-and-play drone market ${ }^{43}$. However, the main challenge of using hydrogen-powered drones is hydrogen availability and transportation. We posit that it would remain highly 
competitive if a DAFC device can provide at least two hours of autonomy and be rated for at least $2 \mathrm{~kW}$ of power.

In the present work, we report a high-performance DAFC stack based on hydrophobic spinel cathodes and optimal stack designs. Firstly, ORR activities of three spinel catalysts $\left(\mathrm{Co}_{2} \mathrm{MnO}_{4}\right.$, $\mathrm{Co}_{2} \mathrm{FeO}_{4}$, and $\left.\mathrm{Co}_{3} \mathrm{O}_{4}\right)$ in the presence of ammonia are examined in DAFCs for the first time. $\mathrm{Co}_{2} \mathrm{MnO}_{4}$ provides superior performance in both ex-situ rotating disk electrode (RDE) experiments and in-situ DAFC tests. A hydrophobic cathode containing a hydrophobic agent (PTFE) in the catalyst layer is carefully designed to improve DAFCs' performance and durability significantly. With optimized conditions, a power density of $410 \mathrm{~mW} \mathrm{~cm}$ is achieved, exhibiting comparable cell performance with the state-of-the-art of DAFC, and the best durability for DAFCs to date is also realized, showing a continuous voltage output for 80 hours at $300 \mathrm{~mA} \mathrm{~cm}{ }^{-2}$ with an average decay rate of $1.6 \mathrm{mV} / \mathrm{h}$. Secondly, a $75 \mathrm{~W}$ DAFC stack comprising five individual $50 \mathrm{~cm}^{2}$ cells, designed by considering the shunt current issue based on graphite bipolar plates, is demonstrated to operate at $90{ }^{\circ} \mathrm{C}$. Finally, a $2 \mathrm{~kW}, 10 \mathrm{kWh}$ DAFC-based system is analyzed to project the system efficiency and energy density and is compared to hydrogen and battery alternatives. This work represents pioneering results and further sheds new light on DAFCs technology development for practical applications.

\section{Evaluation of Spinel ORR catalysts for use in the DAFC cathode}

A variety of transition metal spinels exhibiting significant ORR catalytic activity have been discussed in the literature ${ }^{44}$, in which the ORR activity of spinel catalysts exhibits a volcano trend versus the occupancy of $\mathrm{e}_{\mathrm{g}}$ orbitals in the coordination structure of octahedral sites. For the case of a DAFC cathode, the selection of a specific catalyst should be based on the ORR activity measured at the catalyst/aqueous base interface and the degree of interference by ammonia. 
Ammonia could affect the rate of the ORR at a cathode catalyst surface by adsorption of $\mathrm{NH}_{3}$ and/or surface intermediates formed by AOR at catalyst sites active due to the coordination effect, which may also varies with different occupancy of $e_{g}$ orbitals. Ammonia could also affect the performance of the cathode catalyst by generating a faradaic, ammonia oxidation current at the cathode catalyst, thereby reducing the net cathode current at some given cathode overpotential. Herein, the ORR activities of three $\mathrm{Co}_{2} \mathrm{MO}_{4}$ catalysts $(\mathrm{M}=\mathrm{Mn}, \mathrm{Fe}, \mathrm{Co})$ with different $\mathrm{e}_{\mathrm{g}}$ occupancy of the metallic cation in octahedral sites were evaluated for their activity in the presence of ammonia. Figure 1 presents the $j_{\text {orr }}$ vs. potential (vs. RHE) dependence measured for the three spinel catalysts using a RDE in the presence and absence of ammonia. The effect of ammonia on cathode polarization is seen to be small in all cases, meaning that these spinel catalysts are not deactivated substantially in contact with ammonia nor do they generate a significant AOR current in the relevant cathode potential range. $\mathrm{Co}_{2} \mathrm{MnO}_{4}$ offers the best ORR activity in the presence of ammonia, as it does in an ammonia-free electrolyte. The measured mass activity for $\mathrm{Co}_{2} \mathrm{MnO}_{4}$ at $0.85 \mathrm{~V}$ vs. $\mathrm{RHE}$ at $25{ }^{\circ} \mathrm{C}$ is $119 \mathrm{~mA} \mathrm{mg}{ }^{-1}$, quite higher than that of $\mathrm{Co}_{2} \mathrm{FeO}_{4}\left(40 \mathrm{~mA} \mathrm{mg}^{-1}\right)$ and $\mathrm{Co}_{3} \mathrm{O}_{4}\left(35 \mathrm{~mA} \mathrm{mg}{ }^{-1}\right)$. It should be noted that the ORR activity loss of $\mathrm{Co}_{2} \mathrm{MnO}_{4}$ is much lower than that of Pt catalyst by comparing the shift of their half-wave potential after ammonia is added. The half-wave potential of $\mathrm{Co}_{2} \mathrm{MnO}_{4}$ slightly shifts by $20 \mathrm{mV}$ (from 0.86 to $0.84 \mathrm{~V}$ vs RHE) while Pt catalyst exhibits a shift of half-wave potential by $50 \mathrm{mV}$ (from 0.9 to $0.85 \mathrm{~V}$ vs RHE) in previous work ${ }^{6}$.

To examine their performance as catalysts in DAFCs, $\mathrm{Co}_{2} \mathrm{FeO}_{4}, \mathrm{Co}_{2} \mathrm{MnO}_{4}$, and $\mathrm{Co}_{3} \mathrm{O}_{4}$ catalyst were sprayed on the cathode side of HEM to create catalyst coated membrane (CCM) with hydroxide exchange ionomer (HEI) as described in previous reports ${ }^{6,27}$. DAFCs with the abovementioned cathodes and PtIr/C anodes, were assembled and tested by feeding the anode with a 7 
$\mathrm{M} \mathrm{NH}_{3}$ in $1.25 \mathrm{M} \mathrm{KOH}$ solution. Figure 2 shows that the best cell performance was obtained for the DAFC with the $\mathrm{Co}_{2} \mathrm{MnO}_{4}$ cathode catalyst, agreeing well with the $\mathrm{RDE}$ results. A peak power density of $235 \mathrm{~mW} \mathrm{~cm}{ }^{-2}$ was achieved with the $\mathrm{Co}_{2} \mathrm{MnO}_{4}$ cathode catalyst when operating at temperature of $110^{\circ} \mathrm{C}$. Additionally, a continuous DAFC operation for 63 hours is observed at $300 \mathrm{~mA} \mathrm{~cm}^{-2}$, operating at $100^{\circ} \mathrm{C}$. Although there is still degradation and voltage fluctuation issues, this DAFC durability has been better than the DAFC that has Acta 4020 cathode, which shows a dramatic degradation caused by its specific micropores structure (most active sites are located inside of micropores and thus are easier to be blocked by water) in previous report ${ }^{27,45}$. Based on these results, the $\mathrm{Co}_{2} \mathrm{MnO}_{4}$ catalyst is selected for further investigation.

\section{Facilitating oxygen transport through the cathode by addition of PTFE}

The performance of a cathode in a polymer electrolyte fuel cell is determined jointly by the kinetics of the ORR and the oxygen transport resistance of the cathode catalyst layer (CL), where the latter could have a significant effect on the performance at higher current densities ${ }^{27}$. Previous experimental results suggested that uptake of liquid water by a more hydrophilic cathode CL, can result in oxygen transport limitations ${ }^{46,47}$. With an aqueous solution of ammonia fed to the anode of the DAFC, significant cathode flooding can result from water crossover driven by a steep water concentration gradient between anode and cathode and facilitated by the high water permeability of HEMs. Supplementary Fig. 1 shows that the rate of water exiting the cathode exhaust when the anode feed is aqueous ammonia, is significantly higher than that measured when the anode feed is a hydrogen/water vapor mixture. This indicates a significant rate of liquid water crossover from anode to cathode in DAFC, with most of this water crossing through the cathode catalyst layer before exiting via the cathode exhaust. To reduce this flooding tendency, we used a more hydrophobic cathode CL, where PTFE was incorporated into the catalysts layer coated on a gas 
diffusion layer. As seen in Figure 3a, the contact angle of water for the surface of the PTFEcontaining gas diffusion electrode (GDE) was $140^{\circ}$ compared with $40^{\circ}$ for a CCM using only ionomer as the bonding agent in the CL. Hence, the hydrophobic GDE should present better resistance to flooding by liquid water, and thereby mitigate oxygen transport in the catalyst layer.

The improved oxygen transport rate expected for the hydrophobic GDE, is confirmed by an ORR limiting current test based on a half-MEA design (Supplementary Fig. 2). With neat oxygen at $100 \% \mathrm{RH}$ and $25^{\circ} \mathrm{C}$, the CCM and GDE show a comparable ORR activity (Supplementary Fig. 3). However, when a cathode feed with a small fraction of oxygen $\left(0.2 \% \mathrm{O}_{2}\right.$ in $\left.\mathrm{N}_{2}\right)$ is used and the operating temperature is elevated to $70{ }^{\circ} \mathrm{C}$, the cell with PTFE added to the cathode CL exhibits clearly a higher limiting current, suggesting that the added PTFE can better secure high oxygen transport rate under conditions of significant water crossover.

\section{Performance and durability of a single cell with a cathode CL containing PTFE}

A performance comparison of two DAFCs employing GDE and CCM-based cathodes is shown in Figure 4a. Following area-specific resistance (ASR) correction $\left(85 \mathrm{~m} \Omega \mathrm{cm}^{-2}\right.$ and $69 \mathrm{~m} \Omega \mathrm{cm}^{-2}$ for DAFCs with GDE-based and CCM-based cathode, respectively), the DAFC with the GDEbased cathode (PTFE added) exhibits higher performance than the DAFC with the CCM-based cathode (no PTFE added), confirming the merit of adding PTFE to the cathode CL. We also studied the effect of varying the $\mathrm{Co}_{2} \mathrm{MnO}_{4}$ loading in the cathode on DAFC performance. As seen in Supplementary Fig. 4, the DAFC performance increases with $\mathrm{Co}_{2} \mathrm{MnO}_{4}$ loading in the cathode between $0.2 \mathrm{mg} \mathrm{cm}^{-2}$ to $1.2 \mathrm{mg} \mathrm{cm}^{-2}$, and the $\mathrm{Co}_{2} \mathrm{MnO}_{4}$ loading of $1.2 \mathrm{mg} \mathrm{cm}^{-2}$ provides the best performance showing an improved performance in the low current density regions.

Because PTFE is a non-hydroxide conductive material and can not act as an ionomer to facilitate hydroxide ion transport in the catalysts layer, the high ASR value in the GDE configuration is 
observed. Ion transport's function in the catalyst layer of the GDE configuration is completely dependent on penetrated $\mathrm{KOH}$ across the membrane from the anode feedstock. Consequently, we increase $\mathrm{KOH}$ concentration from $1.25 \mathrm{M}$ to $3 \mathrm{M}$ in anode fuel to reduce the ASR of the cell. As is shown in Figure 4b, rising $\mathrm{KOH}$ concentration can further reduce the ASR of the cell ( $85 \mathrm{~m} \Omega$ $\mathrm{cm}^{-2}$ for $1.25 \mathrm{M} \mathrm{KOH}$ vs. $60 \mathrm{~m} \Omega \mathrm{cm}^{-2}$ for $3 \mathrm{M} \mathrm{KOH}$ ). This leads to a significant increase in cell performance, achieving a peak power density of $410 \mathrm{~mW} \mathrm{~cm}^{-2}$ that is comparable to the performance of the state-of-the-art DAFC $\left(420 \mathrm{~mW} \mathrm{~cm}^{-2}\right)^{12}$.

Most importantly, in addition to the top-performing DAFC enabled by the hydrophobic GDE configuration, the use of the hydrophobic GDE significantly can improve the DAFC stability. Figure $4 \mathrm{c}$ shows the voltage-time plot for a DAFC with a PTFE-containing cathode CL, demonstrating continuous operation for 80 hours at $300 \mathrm{~mA} \mathrm{~cm}^{-2}$ with an average voltage loss rate of $1.6 \mathrm{mV} /$ hour. Both the rate of voltage loss and the accompanying increase in ASR (from $60 \mathrm{~m} \Omega$ $\mathrm{cm}^{2}$ to $90 \mathrm{~m} \Omega \mathrm{cm}^{2}$ ) are much smaller than those recorded for DAFCs with a more hydrophilic cathode CLs and/or with other types of cathode catalysts ${ }^{27}$. It should be noted that a highly stable voltage output is obtained in comparison to a fluctuating voltage output for the CCM based DAFC. Recognizing that the overall performance of the DAFC is largely dominated by anode voltage losses, these results highlight the significance of the cathode catalyst and the prevention of cathode flooding in the determination of the DAFC's performance and stability.

The reason for the degradation rate of $1.6 \mathrm{mV} / \mathrm{h}$, accompanied by an increase in ASR over time, is likely gradual chemical degradation of the HEM to decrease its ion exchange capacity (IEC) during continuous operation, especially in a harsh condition $\left(3 \mathrm{M} \mathrm{KOH} \text { and } 100{ }^{\circ} \mathrm{C}\right)^{29,48,49}$. As shown in Supplementary Fig. 5, a remarkable reduction in ammonia crossover was observed following the $80 \mathrm{~h}$ test: $149 \mathrm{~mA} \mathrm{~cm}{ }^{-2}$ at the end vs. $346 \mathrm{~mA} \mathrm{~cm}^{-2}$ at the start. Such drop in ammonia 
crossover is likely the consequence of HEM degradation. Another possible reason is AOR catalysts deactivation caused by the formation of strongly chemisorbed ammonia oxidation intermediates during the stability test ${ }^{32,50-52}$.

\section{Building and testing a 5-cell DAFC stack of $50 \mathrm{~cm}^{2}$ cell area}

The performance of the $50 \mathrm{~cm}^{2}$ MEA used in the DAFC stack described below, was examined first in a single cell which was assembled using elements of the stack hardware acquired. This hardware imposed an upper limit of $90{ }^{\circ} \mathrm{C}$ on the cell temperature during testing, defined by the softening temperature of polypropylene which is chosen as sealant for the graphite plates to ensure hardware immunity to ammonia. The polarization curve recorded for this single cell is shown in Figure $5 \mathrm{c}$, revealing a peak power density of $300 \mathrm{~mW} \mathrm{~cm}^{-2}$. This peak power is lower than that of the $5 \mathrm{~cm}^{2}$ single cell (Figure 4) due to the lower operating temperature $\left(90^{\circ} \mathrm{C}\right.$ vs. $110{ }^{\circ} \mathrm{C}$ ) and the higher ASR (110 $\mathrm{m} \Omega \mathrm{cm}^{2}$ vs. $\left.60 \mathrm{~m} \Omega \mathrm{cm}^{2}\right)$. The higher ASR was caused, in part, by the higher contact resistance ( $87 \mathrm{~m} \Omega \mathrm{cm}^{2}$, Supplementary Fig. 6), both in the bipolar plates and current collectors. Each bipolar plate is made of two half plates to provide cooling channels, which adds an interface. Additionally, the $50 \mathrm{~cm}^{2}$ single cell graphite hardware was compressed less tightly than our $5 \mathrm{~cm}^{2}$ hardware, resulting in a higher contact resistance at the graphite plate/current collector interface. In a stack, the current collector related resistance is amortized across many cells and, consequently, has a lower impact.

We next looked into optimized stack parameters, including the number of cells to be used and the optimal clamping load. The number of cells selected was determined by the shunt currents calculated for the configuration of our stack hardwared which was based on a common inlet manifold supplying the anode feed to each of the cells. When a fuel feed consisting of ammonia mixed with strong base electrolyte $(\mathrm{KOH})$, enters through such inlet manifold, distributes to the 
individual cells, and recombines and leaves through an exit manifold, the large potential difference between the first and last bipolar plate can cause carbon corrosion. To some extent, the potential difference between the plates is mitigated by potential gradients in the electrolyte caused by shunt currents flowing between cells. Supplementary Note 1 provides a calculation of the shunt currents and plate surface potentials based on an equivalent circuit (Supplementary Fig. 7) representing the anode manifold of a five-cell stack. At single cell voltage of $0.5 \mathrm{~V}$, the highest plate surface potential in a 5-cell stack of manifold dimensions employed, is calculated about $1.15 \mathrm{~V}$ vs RHE, which avoids severe carbon corrosion. A stack of larger cells number could be built by using bipolar plates with an insulating frame and conductive active area, so that the manifold surfaces are not conductive. The optimal clamping load for the stack was evaluated before DAFC stack assembly, by examining the effect of a range of torques (1.36 N.m, 2.03 N.m, 2.71 N.m, and 3.34 N.m) on the quality of the interefacial contact (Supplementary Fig. 8). Pressure paper tests (Supplementary Fig. 9) showed that the quality of the contact increased with the torque all the way up to 3.34 N.m and we consequently used a torque of 3.34 N.m for clamping the stack.

The assembled 5-cell DAFC stack which generated $75 \mathrm{~W}$ of electric power, is illustrated in Figure 5a and it's polrization characteristic is presented in Figure 5b. Remarkebly, the average peak power density of $300 \mathrm{~mW} \mathrm{~cm}{ }^{-2}$ for the cells in the stack is identical to the power density of the single cell with the same surface area. The PTFE containing cathode CL and in-house fabricated spinel catalyst were used in the five MEAs in the stack. The variation of the DAFC stack voltage over time operating at $90^{\circ} \mathrm{C}$ and constant current of $15 \mathrm{~A}$, is shown in Figure $5 \mathrm{~d}$. This stack was operated first for $3.5 \mathrm{~h}$ before shutting it down for the night, and the voltage degradation is seen to slightly recover on stack restart on the next day. The beneficial effect of 
open-cicuit conditions on recovery of the DAFC anode performance has been explained by reductive desorption of strongly bonded AOR intermediates at the PtIr catalyst ${ }^{50}$.

\section{Projections in 2 kW, 10 kWh DAFC-based drone power system}

Based on the DAFC stack prototype developed, we consider here the possible use of a DAFCbased power system using liquid ammonia as the fuel on board for powering a drone. We have made projections of the competitiveness of a drone power source based on a DAFC vs. a PEMFC fueled by hydrogen and vs. battery alternatives. A DAFC system described in Figure 6a, includes a stack, a fuel tank, liquid ammonia fuel, and the balance of plant (BOP) which includes a compressor-expander module for the airflow, membrane humidifier, anode fuel mixer, recycle pump, condenser, and an ammonia scrubber. Projections of the mass and volume for a $2 \mathrm{~kW}, 10$ $\mathrm{kWh}$ drone power system are shown in Supplementary Table 1. Using the measured polariation curve for the $75 \mathrm{~W}$ stack, the calculated system efficiency is given as a function of ammonia crossover in Figure 6b, indicating that the loss of ammonia by crossover measured in such DAFCs has a strong impact on system efficiency. For example, with an ammonia crossover rate of 346 $\mathrm{mA} \mathrm{cm}{ }^{-2}$ measured for one single DAFC tested near $100^{\circ} \mathrm{C}$ (Supplementary Fig. 5), the calculated system efficiency at cell current of $300 \mathrm{~mA} \mathrm{~cm}^{-2}$ generated at cell voltage of $0.47 \mathrm{~V}$, is $17 \%$. At the same cell current and voltage, system efficiency will be improved to $35 \%$ or $33 \%$ if ammonia crossover could be reduced to $0 \mathrm{~mA} \mathrm{~cm}^{-2}$ or $25 \mathrm{~mA} \mathrm{~cm}^{-2}$, respectively. As the system efficiency have been calculated based on the polarization characteristic of the $75 \mathrm{~W}$ stack (Figure $5 \mathrm{~b}$ ), and the efficiency can also be increased by opreation with the same catalysts at somewhat higher cell temperature or, ultimately, with advanced MEAs of higher intrinsic performance. The most important barrier, however, to higher DAFC effeciency, is loss of fuel by ammonia crossover that could be most effectively treated using a selective barrier for blocking ammonia and 
simultaneously maintaining high $\mathrm{OH}^{-}$ion conductivity. For instance, system efficiency of $42 \%$ could be reached with the ultimate target $-0.58 \mathrm{~V}$ at $300 \mathrm{~mA} \mathrm{~cm}-2$ and ammonia crossover of 25 $\mathrm{mA} \mathrm{cm}{ }^{-2}$.

Because energy density is the key metric for drones, specific energy densities (mass and volume) of $2 \mathrm{~kW}, 10 \mathrm{kWh}$ DAFC-based drone power systems were estimated by calculating the contributions of the stack, the full fuel tank, and BOP to the system mass and volume (Supplementary Note 2). As seen in Figure 6c, with operation point of the DAFC stack of $0.47 \mathrm{~V}$ per cell at $300 \mathrm{~mA} \mathrm{~cm}^{-2}$ and ammonia crossover of $346 \mathrm{~mA} \mathrm{~cm}^{-2}$, the gravimetric and volumetric energy densities are $0.4 \mathrm{kWh} \mathrm{kg}^{-1}$ and $0.3 \mathrm{kWh} \mathrm{L}^{-1}$, respectively. With an ultimate target of 0.58 $\mathrm{V}$ at $300 \mathrm{~mA} \mathrm{~cm}^{-2}$ and ammonia crossover limited to $25 \mathrm{~mA} \mathrm{~cm}^{-2}$, the gravimetric and volumetric energy densities could be improved to $0.65 \mathrm{kWh} \mathrm{kg}^{-1}$ and $0.5 \mathrm{kWh} \mathrm{L}^{-1}$, respectively. In comparison, the hydrogen fueled system has energy densities of $0.52 \mathrm{kWh} \mathrm{kg}^{-1}$ and $0.22 \mathrm{kWh} \mathrm{L}^{-1}$, and the battery possesses energy densities of $0.2 \mathrm{kWh} \mathrm{kg}^{-1}$ and $0.4 \mathrm{kWh} \mathrm{L}^{-1}$. The results show that the DAFC-based power system for drones would be highly competitive by following a significant reduction of the ammonia crossover and further enhancement of the cell power output. Further work along these lines has been pursued.

\section{Conclusions}

In summary, we report here significant advancements in polymer electrolyte DAFC technology at the cell and the stack levels. The cell performance and durability have both been well advanced by use of a spinel ORR catalyst, $\mathrm{Co}_{2} \mathrm{MnO}_{4}$, which was synthesized in-house and examined in DAFC cathode for the first time. This catalyst offered the best performance in both ex-situ RDE measurements and DAFC tests. A hydrophobic DAFC cathode employing the $\mathrm{Co}_{2} \mathrm{MnO}_{4}$ catalyst 
enabled a high peak power density of $410 \mathrm{~mW} \mathrm{~cm}^{-2}$, and importantly, the best DAFC durability reported to date, an 80 hours run at $300 \mathrm{~mA} \mathrm{~cm}^{-2}$. A first DAFC stack of $75 \mathrm{~W}$ was successfully assembled using the hydrophobic $\mathrm{Co}_{2} \mathrm{MnO}_{4}$ cathodes and PtIr/C anode catalysts. The 5 cell, 50 $\mathrm{cm}^{2}$ stack was built of graphite hardware and exhibited average cell performance practically identical to that of a single $50 \mathrm{~cm}^{2}$ cell. The shunt currents estimated from the dimensions of the manifold in the stack, defined the number of cells allowed in the (unmodified) stack. Finally, a 2 kW, 10 kWh DAFC-based power system for drones has been evaluated vs. a hydrogen fueled FC system and a Li-ion battery. The work presented in this manuscript demonstrates the state-of-theart in DAFC technology, and provides critical insights towards the further development of highperformance DAFC power sources that could be used as energy-efficient, carbon-neutral power systems for transportation.

\section{Acknowledgments}

The information, data, or work presented herein was funded in part by the Advanced Research Projects Agency-Energy (ARPA-E), U.S. Department of Energy, under Award Number DEAR0000805. The views and opinions of authors expressed herein do not necessarily state or reflect those of the United States Government or any agency thereof.

\section{Competing interests}

The PiperION membranes and ionomers were provided for free by Versogen, a company cofounded by some of the coauthors of this article. 


\section{Methods}

\section{Synthesis of spinel catalysts}

$\mathrm{Co}_{2} \mathrm{MO}_{4}(\mathrm{M}=\mathrm{Mn}, \mathrm{Fe}, \mathrm{Co})$ was synthesized as follows ${ }^{44} \cdot \mathrm{Co}(\mathrm{OAc})_{2} \cdot 4 \mathrm{H}_{2} \mathrm{O}(127.5 \mathrm{mg}$, SigmaAldrich) was firstly dissolved in $24 \mathrm{~mL}$ ethanol, and then $60 \mathrm{mg}$ Vulcan XC-72R carbon was added into the solution. The mixture was sonicated for $10 \mathrm{~min}$ and following by adding dropwise the mixture of $0.44 \mathrm{~mL}$ ammonia $(28 \mathrm{wt} \%$ ) and $20 \mathrm{~mL}$ ethanol. After the suspension was sonicated for $10 \mathrm{~min}$, the solution of $\mathrm{Mn}(\mathrm{OAc})_{2} \cdot 4 \mathrm{H}_{2} \mathrm{O}\left(62.5 \mathrm{mg}\right.$, Acros), $\mathrm{Fe}\left(\mathrm{NO}_{3}\right)_{3} \cdot 9 \mathrm{H}_{2} \mathrm{O}(103 \mathrm{mg}$, SigmaAldrich), or $\mathrm{Co}(\mathrm{OAc})_{2} \cdot 4 \mathrm{H}_{2} \mathrm{O}(63.8 \mathrm{mg}$, Sigma-Aldrich) dissolved in $1.5 \mathrm{~mL}$ water was added. The final suspension was heated at $60^{\circ} \mathrm{C}$ for $12 \mathrm{~h}$ under reflux and then transferred to Teflon autoclave for the hydrothermal reaction at $150{ }^{\circ} \mathrm{C}$ for $3 \mathrm{~h}$. The $\mathrm{Co}_{2} \mathrm{MO}_{4}$ product was collected by centrifugation and thoroughly washed with water and ethanol, then dried under vacuum.

\section{Ex-situ RDE experiments}

The ORR catalysts sample ( $1 \mathrm{mg}$ ) was ultrasonically dispersed in $1 \mathrm{~mL}$ mixed solvent of ethanol and water $(1: 1 \mathrm{v} / \mathrm{v})$, and then $10 \mu \mathrm{L}$ of Nafion solution ( $5 \mathrm{wt} \%$ in ethanol) was added to the suspension. The suspension was dropped onto a rotating disk electrode $(5.0 \mathrm{~mm}$ in diameter) with a glassy carbon substrate and dried for $2 \mathrm{~h}$ at room temperature to fabricate the electrodes. The catalyst loading was $0.028 \mathrm{mg} \mathrm{cm}^{-2}$. The electrochemical measurement on RDE was performed in a standard three-electrode system controlled by Biologic VMP-2 potentiostat. A clean graphite rod is used as the counter electrode, and a saturated $\mathrm{Ag} / \mathrm{AgCl}$ electrode is used as the reference electrode. 


\section{Membrane-electrode-assembles (MEAs) preparation}

Anode was prepared by coating PtIr/C catalysts on carbon cloth with the catalyst loading of 2 $\mathrm{mg}_{\mathrm{PGM}} \mathrm{cm}^{-2}$. Utilizing isopropanol as the solvent and PiperION TP-100 ionomer (PtIr/C: PiperIon=9:1), the anode PtIr/C catalyst ink was ultra-sonicated in an ice-water bath for $1 \mathrm{~h}$ to form the uniform dispersion. The CCM-based cathode was prepared by spraying spinel catalysts with a weight ratio of 8:2 to PiperION TP-100 ionomer. The loading of spinel catalysts was 0.8 $\mathrm{mg} \mathrm{cm}{ }^{-2}$. The GDE-based hydrophobic cathode was prepared by scrubbing $\mathrm{CoMn}_{2} \mathrm{O}_{4}$ catalysts with a weight ratio of 6.5:3.5 to PTFE binder. The loading was determined to $0.2,0.8$ and $1.2 \mathrm{mg}$ $\mathrm{cm}^{-2}$, respectively.

\section{Single-cell and stack evaluation test}

The default test conditions for a single-cell with an active area of $5 \mathrm{~cm}^{2}$ or $50 \mathrm{~cm}^{2}$ were anode fuel: $5 \mathrm{ml} \mathrm{min}{ }^{-1}$ at 2 bar $_{\mathrm{g}}$ for the polarization curves test and $2 \mathrm{ml} \mathrm{min}^{-1}$ at 2 bar $_{\mathrm{g}}$ for the durability test; cathode fuel: $500 \mathrm{ml} \mathrm{min}-1 \mathrm{O}_{2}$ at $100 \% \mathrm{RH}$ at $2 \mathrm{bar}_{\mathrm{g}}$; cell temperature: $110^{\circ} \mathrm{C}$ for the polarization curves test and $100{ }^{\circ} \mathrm{C}$ for the durability test. The default test conditions for a 5 -cell stack were anode fuel: $25 \mathrm{ml} \mathrm{min}{ }^{-1}$ at 2 barg $_{\mathrm{g}}$ for the polarization curve test and $15 \mathrm{ml} \mathrm{min}^{-1}$ at 2 bar $_{\mathrm{g}}$ for the

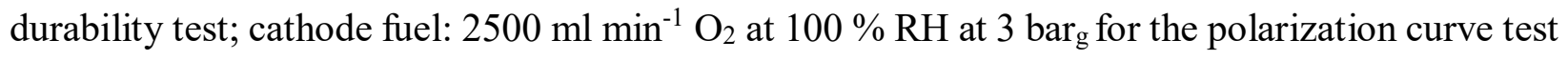
and $1500 \mathrm{ml} \mathrm{min}-1 \mathrm{O}_{2}$ at $100 \% \mathrm{RH}$ at 3 bar $_{\mathrm{g}}$ for the durability test; cell temperature: $90{ }^{\circ} \mathrm{C}$.

\section{Data Availability}

The data that support the plots within this paper and other findings of this study are available from the corresponding author upon reasonable request. 


\section{References}

1 de Blas, I., Mediavilla, M., Capellan-Perez, I. \& Duce, C. The limits of transport decarbonization under the current growth paradigm. Energy Strateg Rev 32, doi:10.1016/j.esr.2020.100543 (2020).

2 Lefevre, J. et al. A pathway design framework for sectoral deep decarbonization: the case of passenger transportation. Clim Policy 21, 93-106, doi:10.1080/14693062.2020.1804817 (2021).

3 Tayarani, M., Poorfakhraei, A., Nadafianshahamabadi, R. \& Rowangould, G. Can regional transportation and land-use planning achieve deep reductions in GHG emissions from vehicles? Transport Res D-Tr E 63, 222-235, doi:10.1016/j.trd.2018.05.010 (2018).

4 Valera-Medina, A., Xiao, H., Owen-Jones, M., David, W. I. F. \& Bowen, P. J. Ammonia for power. Progress in Energy and Combustion Science 69, 63-102, doi:10.1016/j.pecs.2018.07.001 (2018).

5 Kobayashi, H., Hayakawa, A., Somarathne, K. D. K. A. \& Okafor, E. C. Science and technology of ammonia combustion. P Combust Inst 37, 109-133, doi:10.1016/j.proci.2018.09.029 (2019).

6 Zhao, Y. et al. An Efficient Direct Ammonia Fuel Cell for Affordable Carbon-Neutral Transportation. Joule 3, 2472-2484, doi:10.1016/j.joule.2019.07.005 (2019).

7 Lan, R. \& Tao, S. Ammonia as a suitable fuel for fuel cells. Frontiers in Energy Research 2, 1-4, doi:10.3389/fenrg.2014.00035 (2014).

8 Smith, C., Hill, A. K. \& Torrente-Murciano, L. Current and future role of Haber-Bosch ammonia in a carbon-free energy landscape. Energy \& Environmental Science 13, 331-344, doi:10.1039/c9ee02873k (2020).

9 Hansson, J., Brynolf, S., Fridell, E. \& Lehtveer, M. The Potential Role of Ammonia as Marine FuelBased on Energy Systems Modeling and Multi-Criteria Decision Analysis. Sustainability-Basel 12, doi:10.3390/su12083265 (2020).

10 Cesaro, Z., Ives, M., Nayak-Luke, R., Mason, M. \& Banares-Alcantara, R. Ammonia to power: Forecasting the levelized cost of electricity from green ammonia in large-scale power plants. Appl Energ 282, doi:10.1016/j.apenergy.2020.116009 (2021).

11 MacFarlane, D. R. et al. A Roadmap to the Ammonia Economy. Joule 4, 1186-1205, doi:10.1016/j.joule.2020.04.004 (2020).

12 Gottesfeld, S. The Direct Ammonia Fuel Cell and a Common Pattern of Electrocatalytic Processes. Journal of the Electrochemical Society 165, J3405-J3412, doi:10.1149/2.0431815jes (2018).

13 Abbasi, R. et al. Low-temperature direct ammonia fuel cells: Recent developments and remaining challenges. Current Opinion in Electrochemistry 21, 335-344, doi:10.1016/j.coelec.2020.03.021 (2020).

14 Guo, Y., Pan, Z. \& An, L. Carbon-free sustainable energy technology: Direct ammonia fuel cells. Journal of Power Sources 476, 228454, doi:10.1016/j.jpowsour.2020.228454 (2020).

15 Santamaria, A. D. \& Mortazavi, M. Aqueous Ammonia Wetting of Gas-Diffusion Media for Electrochemical Cells. Journal of The Electrochemical Society 167, 104507, doi:10.1149/19457111/ab995e (2020).

16 Achrai, B. et al. A Direct Ammonia Fuel Cell with a KOH-Free Anode Feed Generating $180 \mathrm{~mW} \mathrm{cm(-}$ 2)at 120 degrees C. Journal of the Electrochemical Society 167, 134518, doi:10.1149/19457111/abbdd1 (2020).

17 Jeerh, G., Zhang, M. F. \& Tao, S. W. Recent progress in ammonia fuel cells and their potential applications. Journal of Materials Chemistry A 9, 727-752, doi:10.1039/d0ta08810b (2021).

18 Lan, R. \& Tao, S. W. Direct Ammonia Alkaline Anion-Exchange Membrane Fuel Cells. Electrochem. Solid State Lett. 13, B83-B86, doi:10.1149/1.3428469 (2010). 
Assumpcao, M. et al. Direct ammonia fuel cell performance using PtIr/C as anode electrocatalysts. International Journal of Hydrogen Energy 39, 5148-5152, doi:10.1016/j.ijhydene.2014.01.053 (2014).

20 Assumpção, M. H. M. T. et al. Investigation of Pdlr/C electrocatalysts as anode on the performance of direct ammonia fuel cell. Journal of Power Sources 268, 129-136, doi:10.1016/j.jpowsour.2014.06.025 (2014).

21 Assumpção, M. H. M. T. et al. Oxidation of ammonia using PtRh/C electrocatalysts: Fuel cell and electrochemical evaluation. Applied Catalysis B: Environmental 174-175, 136-144, doi:10.1016/j.apcatb.2015.02.021 (2015).

22 Suzuki, S., Muroyama, H., Matsui, T. \& Eguchi, K. Fundamental studies on direct ammonia fuel cell employing anion exchange membrane. Journal of Power Sources 208, 257-262, doi:10.1016/j.jpowsour.2012.02.043 (2012).

23 Lan, R. \& Tao, S. W. Ammonia Carbonate Fuel Cells Based on a Mixed NH4+/H+ Ion Conducting Electrolyte. ECS Electrochem. Lett. 2, F37-F40, doi:10.1149/2.007305eel (2013).

24 Lee, K. R., Song, D., Park, S. B. \& Han, J. I. A direct ammonium carbonate fuel cell with an anion exchange membrane. Rsc Advances 4, 5638-5641, doi:10.1039/c3ra44057e (2014).

25 Okanishi, T., Katayama, Y., Muroyama, H., Matsui, T. \& Eguchi, K. SnO2-modified Pt electrocatalysts for ammonia-fueled anion exchange membrane fuel cells. Electrochimica Acta 173, 364-369, doi:10.1016/j.electacta.2015.05.066 (2015).

26 Silva, J. C. M. et al. PtAu/C electrocatalysts as anodes for direct ammonia fuel cell. Appl. Catal. AGen. 490, 133-138, doi:10.1016/j.apcata.2014.11.015 (2015).

27 Wang, T., Zhao, Y., Setzler, B. P. \& Yan, Y. S. Improving Performance and Durability of Low Temperature Direct Ammonia Fuel Cells: Effect of Backpressure and Oxygen Reduction Catalysts. Journal of the Electrochemical Society 168, doi:10.1149/1945-7111/abdcca (2021).

$28 \mathrm{Li}$, Y. et al. High-Performance Ammonia Oxidation Catalysts for Anion-Exchange Membrane Direct Ammonia Fuel Cells. Energy \& Environmental Science, doi:10.1039/DOEE03351K (2021).

29 Wang, J. H. et al. Poly(aryl piperidinium) membranes and ionomers for hydroxide exchange membrane fuel cells. Nat Energy 4, 392-398, doi:10.1038/s41560-019-0372-8 (2019).

30 Uribe, F. A., Gottesfeld, S. \& Zawodzinski, T. A. Effect of ammonia as potential fuel impurity on proton exchange membrane fuel cell performance. Journal of the Electrochemical Society 149, A293-A296, doi:10.1149/1.1447221 (2002).

31 Uribe, F. A., Gottesfeld, S. \& Zawodzinski, T. A. Effect of ammonia as potential fuel impurity on proton exchange membrane fuel cell performance. J Electrochem Soc 149, A293-A296 (2002).

32 Herron, J. A., Ferrin, P. \& Mavrikakis, M. Electrocatalytic Oxidation of Ammonia on TransitionMetal Surfaces: A First-Principles Study. J. Phys. Chem. C 119, 14692-14701, doi:10.1021/jp512981f (2015).

33 Shaigan, N., Yuan, X. Z., Girard, F., Fatih, K. \& Robertson, M. Standardized testing framework for quality control of fuel cell bipolar plates. Journal of Power Sources 482, doi:10.1016/j.jpowsour.2020.228972 (2021).

34 Vargas, J. V. C., Ordonez, J. C. \& Bejan, A. Constructal PEM fuel cell stack design. Int J Heat Mass Tran 48, 4410-4427, doi:10.1016/j.ijheatmasstransfer.2005.05.009 (2005).

35 Barbir, F. in Mini-Micro Fuel Cells. (eds S. Kakaç, A. Pramuanjaroenkij, \& L. Vasiliev) 27-46 (Springer Netherlands).

36 Wlodarczyk, R. Properties of graphite-stainless steel composite in bipolar plates in simulated anode and cathode environments of PEM fuel cells. Mater Sci-Poland 32, 487-497, doi:10.2478/s13536-014-0229-6 (2014).

37 Singh, R. S., Gautam, A. \& Rai, V. Graphene-based bipolar plates for polymer electrolyte membrane fuel cells. Front Mater Sci 13, 217-241, doi:10.1007/s11706-019-0465-0 (2019). 
Song, Y. X. et al. Review on current research of materials, fabrication and application for bipolar plate in proton exchange membrane fuel cell. International Journal of Hydrogen Energy 45, 2983229847, doi:10.1016/j.ijhydene.2019.07.231 (2020).

39 Wu, C. W., Liu, B., Wei, M. Y. \& Zhang, W. Mechanical Response of a Large Fuel Cell Stack to Impact: A Numerical Analysis. Fuel Cells 15, 344-351, doi:10.1002/fuce.201400153 (2015).

40 Zhang, W. \& Wu, C. W. Effect of Clamping Load on the Performance of Proton Exchange Membrane Fuel Cell Stack and Its Optimization Design: A Review of Modeling and Experimental Research. J Fuel Cell Sci Tech 11, doi:10.1115/1.4026070 (2014).

41 Lee, S. Y., Lee, K. S. \& Um, S. The structural variation of the gas diffusion layer and a performance evaluation of polymer electrolyte fuel cells as a function of clamping pressure. J Mech Sci Technol 22, 565-574, doi:10.1007/s12206-007-1211-6 (2008).

42 Admirator. Top 10 Drones with the Longest Flight Times. (2020).

43 Arat, H. T. \& Surer, M. G. Experimental investigation of fuel cell usage on an air Vehicle's hybrid propulsion system. International Journal of Hydrogen Energy 45, 26370-26378, doi:10.1016/j.ijhydene.2019.09.242 (2020).

44 Wei, C. et al. Cations in Octahedral Sites: A Descriptor for Oxygen Electrocatalysis on TransitionMetal Spinels. Advanced Materials 29, doi:10.1002/adma.201606800 (2017).

45 Wang, Y. C. et al. Constructing a Triple-Phase Interface in Micropores to Boost Performance of $\mathrm{Fe} / \mathrm{N} / \mathrm{C}$ Catalysts for Direct Methanol Fuel Cells. Acs Energy Lett 2, 645-650, doi:10.1021/acsenergylett.7b00071 (2017).

46 Pasaogullari, U. \& Wang, C. Y. Liquid water transport in gas diffusion layer of polymer electrolyte fuel cells. Journal of the Electrochemical Society 151, A399-A406, doi:10.1149/1.1646148 (2004).

47 Das, P. K., Li, X. G. \& Liu, Z. S. Analysis of liquid water transport in cathode catalyst layer of PEM fuel cells. International Journal of Hydrogen Energy 35, 2403-2416, doi:10.1016/j.ijhydene.2009.12.160 (2010).

48 Dekel, D. R. et al. The critical relation between chemical stability of cations and water in anion exchange membrane fuel cells environment. Journal of Power Sources 375, 351-360, doi:10.1016/j.jpowsour.2017.08.026 (2018).

49 Dekel, D. R. et al. Effect of Water on the Stability of Quaternary Ammonium Groups for Anion Exchange Membrane Fuel Cell Applications. Chemistry of Materials 29, 4425-4431, doi:10.1021/acs.chemmater.7b00958 (2017).

50 Li, Z. F., Wang, Y. X. \& Botte, G. G. Revisiting the electrochemical oxidation of ammonia on carbonsupported metal nanoparticle catalysts. Electrochimica Acta 228, 351-360, doi:10.1016/j.electacta.2017.01.020 (2017).

51 Bunce, N. J. \& Bejan, D. Mechanism of electrochemical oxidation of ammonia. Electrochimica Acta 56, 8085-8093, doi:10.1016/j.electacta.2011.07.078 (2011).

52 Fu, G.-t. et al. I-Lysine mediated synthesis of platinum nanocuboids and their electrocatalytic activity towards ammonia oxidation. Journal of Materials Chemistry A 2, 17883-17888, doi:10.1039/c4ta03601h (2014). 

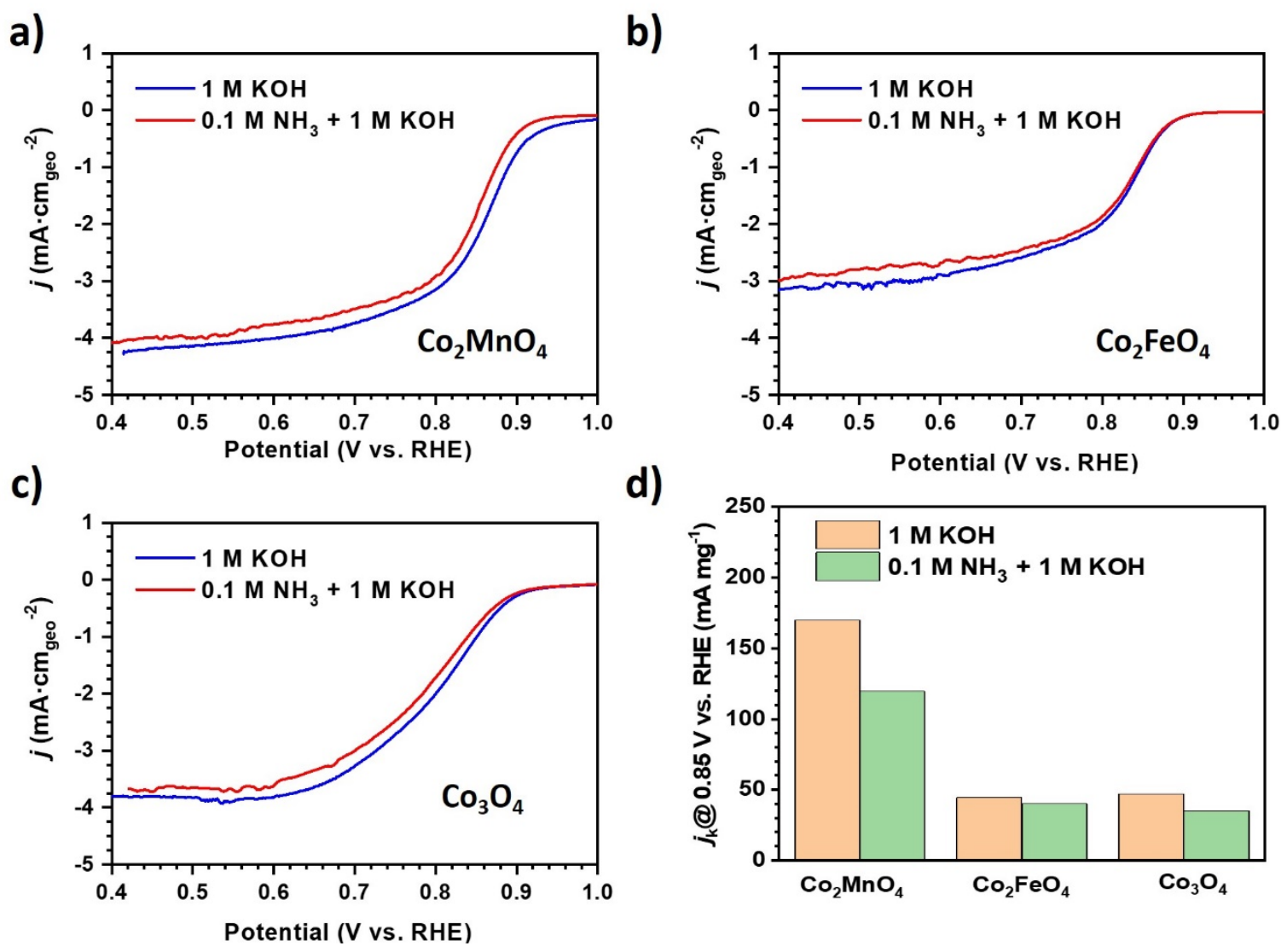

d)

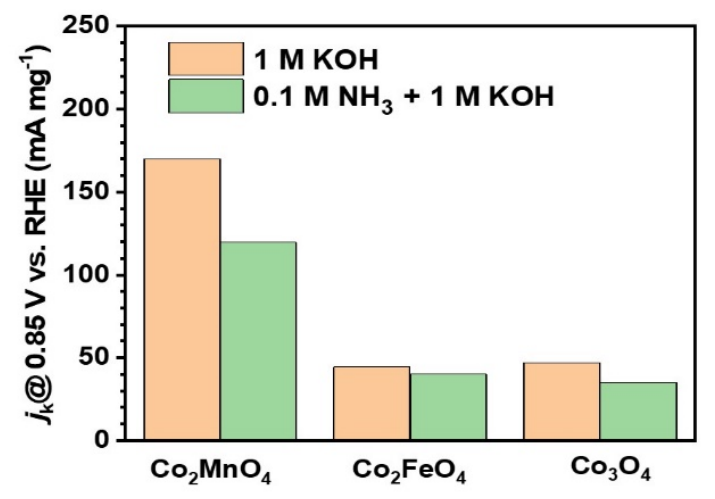

Fig. 1 | The ORR polarization curves in $1 \mathrm{M} \mathrm{KOH}$ and $0.1 \mathrm{M} \mathrm{NH}_{3}-1 \mathrm{M} \mathrm{KOH}$ solutions at room temperature. a, $\mathrm{Co}_{2} \mathrm{MnO}_{4} . \mathbf{b}, \mathrm{Co}_{2} \mathrm{FeO}_{4} . \mathbf{c}, \mathrm{Co}_{3} \mathrm{O}_{4}$. d, The comparison of $j_{\mathrm{k}}$ at $0.85 \mathrm{~V}$ vs. RHE. 

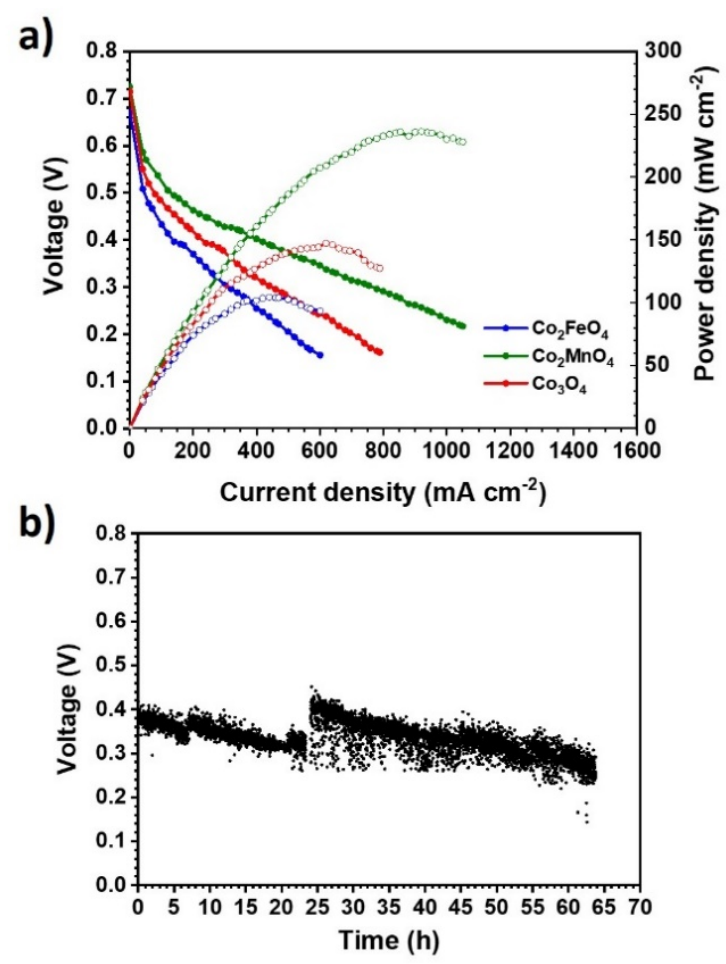

Fig. 2 | Performance and durability of DAFCs. a, Polarization and power density curves of DAFCs with different spinel catalysts based CCMs. Test conditions: cell temperature of $110{ }^{\circ} \mathrm{C}, 5 \mathrm{~mL} \mathrm{~min}^{-1} 7 \mathrm{M} \mathrm{NH}_{3}$ in $1.25 \mathrm{M} \mathrm{KOH}$ at 2 barg $_{\mathrm{g}}, 0.5 \mathrm{~L} \mathrm{~min}^{-1} \mathrm{O}_{2}$ with a humidifier at $95{ }^{\circ} \mathrm{C}$ and 2 bar $_{\mathrm{g}}$. $\mathbf{b}$, The durability test of the DAFC with different spinel catalysts based CCMs. Test conditions: at $300 \mathrm{~mA} \mathrm{~cm}{ }^{-2}$, cell temperature of $100^{\circ} \mathrm{C}, 2 \mathrm{~mL} \mathrm{~min}^{-1} 7 \mathrm{M} \mathrm{NH}_{3}$ in $1.25 \mathrm{M}$ $\mathrm{KOH}$ at 2 barg $_{\mathrm{g}} 0.5 \mathrm{~L} \mathrm{~min}^{-1} \mathrm{O}_{2}$ with a humidifier at $95{ }^{\circ} \mathrm{C}$ and 2 barg. Anode: $2 \mathrm{mg}_{\mathrm{PGM}} \mathrm{cm}^{-2} \mathrm{PtIr} / \mathrm{C}$ with PiperION PAPTP-100 ionomer. HEM: PiperION membrane (13 $\mu \mathrm{m}$ thickness, reinforced PAP-TP-85). Cathode: $0.8 \mathrm{mg}$ spinel catalysts with $20 \mathrm{wt} \%$ PiperION PAP-TP-100 ionomer. 
a)
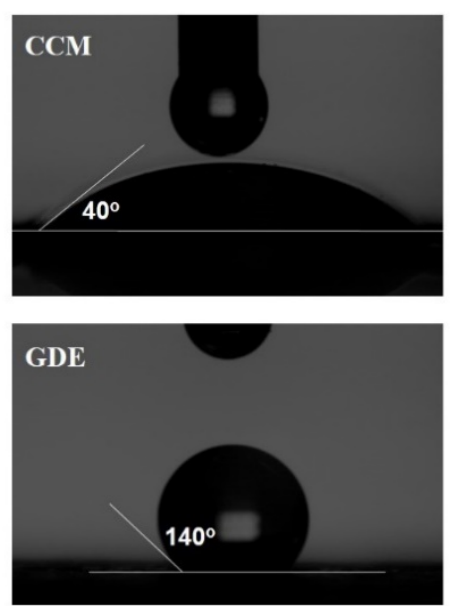

b)

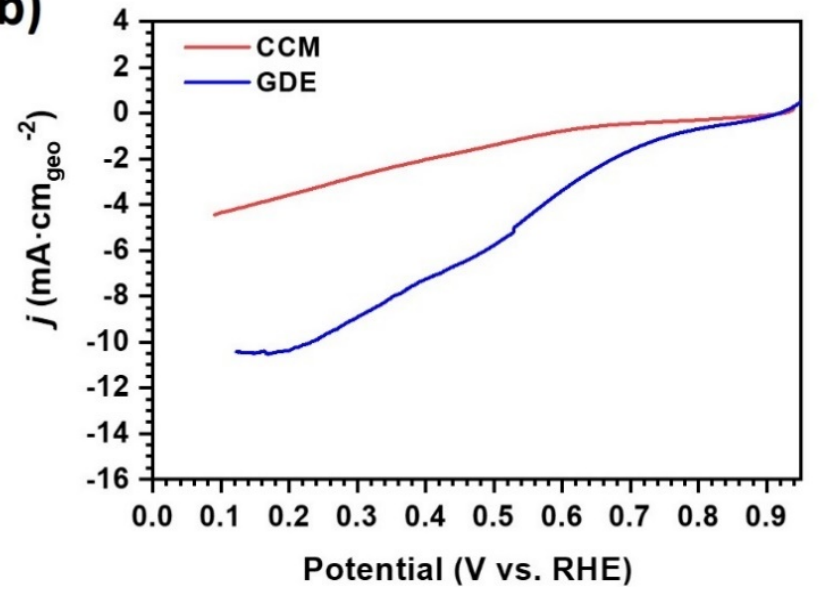

Fig. 3 | Characterization of hydrophobicity and the ORR limiting current of the cathodes with different configurations. a, Contact angle images of $\mathrm{Co}_{2} \mathrm{MnO}_{4}$ based CCM and GDE. b, ORR polarization curves of $\mathrm{Co}_{2} \mathrm{MnO}_{4}$ based CCM and GDE, respectively. Test conditions: $70{ }^{\circ} \mathrm{C}$ with a mixed flow $\left(0.2 \% \mathrm{O}_{2}\right.$ in $\left.\mathrm{N}_{2}\right)$ at $100 \mathrm{~mL} \mathrm{~min}^{-1}$ and $100 \%$ RH. 
a)

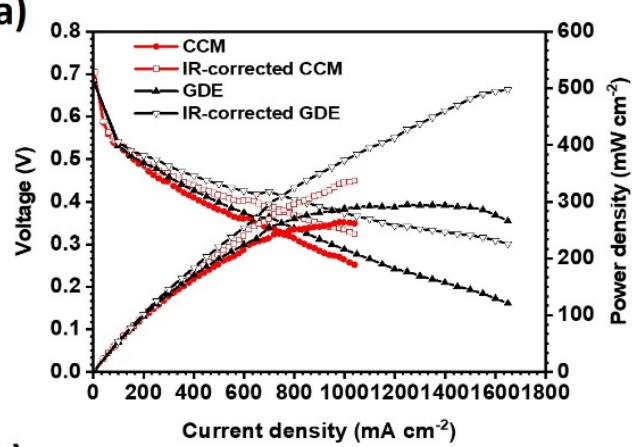

c)

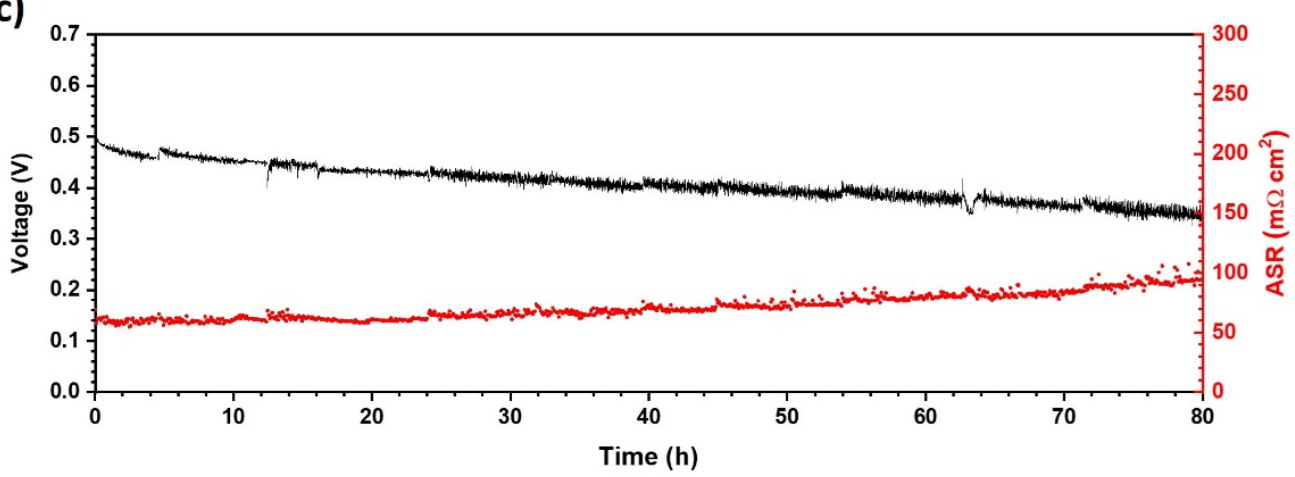

b)

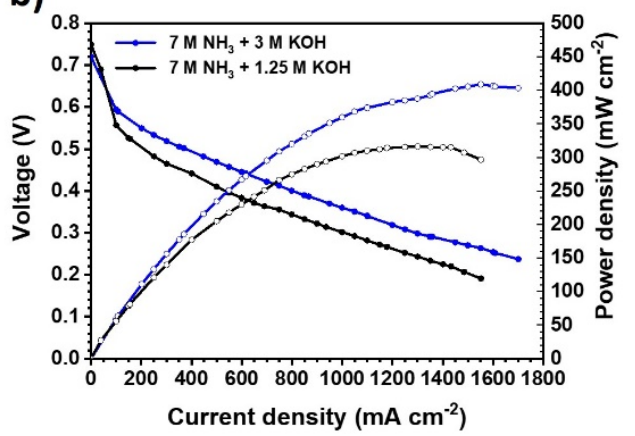

Fig. 4 | Performance and durability of DAFCs with $\mathrm{Co}_{2} \mathrm{MnO}_{4}$ catalysts. a, Polarization and power density curves of DAFCs with $\mathrm{Co}_{2} \mathrm{MnO}_{4}$ based CCM and GDE, respectively. $\mathbf{b}$, Comparison of polarization curves of the DAFC with $\mathrm{Co}_{2} \mathrm{MnO}_{4}$ based GDE at different $\mathrm{KOH}$ concentrations in anode feed. Test conditions: cell temperature of $110^{\circ} \mathrm{C}$, $5 \mathrm{~mL} \mathrm{~min}^{-1} 7 \mathrm{M} \mathrm{NH}_{3}$ in $1.25 \mathrm{M}$ or $3 \mathrm{M} \mathrm{KOH}$ at 2 barg $_{\mathrm{g}} 0.5 \mathrm{~L} \mathrm{~min}^{-1} \mathrm{O}_{2}$ with a humidifier at $95{ }^{\circ} \mathrm{C}$ and 2 barg. c, The durability test of the DAFC with $\mathrm{Co}_{2} \mathrm{MnO}_{4}$ based GDE. Test conditions: at $300 \mathrm{~mA} \mathrm{~cm}{ }^{-2}$, cell temperature of $100{ }^{\circ} \mathrm{C}$, $2 \mathrm{~mL} \mathrm{~min}^{-1} 7 \mathrm{M} \mathrm{NH}_{3}$ in $3 \mathrm{M} \mathrm{KOH}$ at 2 barg $_{\mathrm{g}} 0.5 \mathrm{~L} \mathrm{~min}^{-1} \mathrm{O}_{2}$ with a humidifier at $95^{\circ} \mathrm{C}$ and 2 barg. Anode: $2 \mathrm{mg}_{\mathrm{PGM}} \mathrm{cm}^{-}$

${ }^{2} \mathrm{PtIr} / \mathrm{C}$ with PiperION PAP-TP-100 ionomer. HEM: PiperION membrane (13 $\mu \mathrm{m}$ thickness, reinforced PAP-TP-85). Cathode: $1.2 \mathrm{mgcm}^{-2} \mathrm{Co}_{2} \mathrm{MnO}_{4}$ with $20 \mathrm{wt} \%$ PiperION PAP-TP-100 ionomer. 
a)

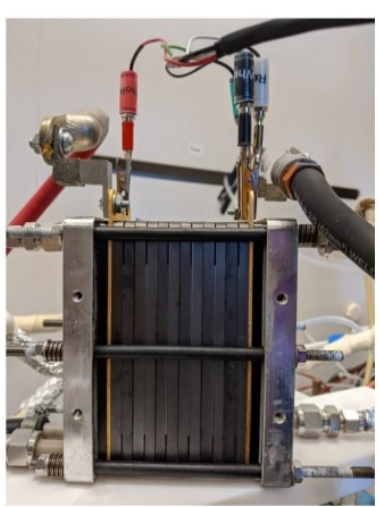

c)

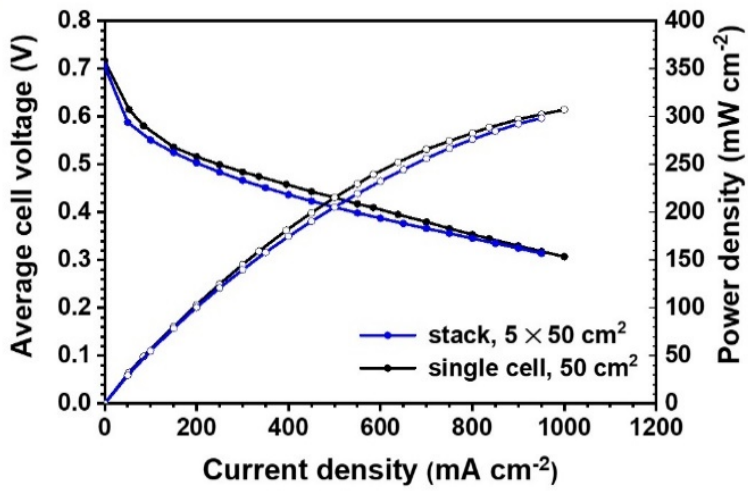

b)

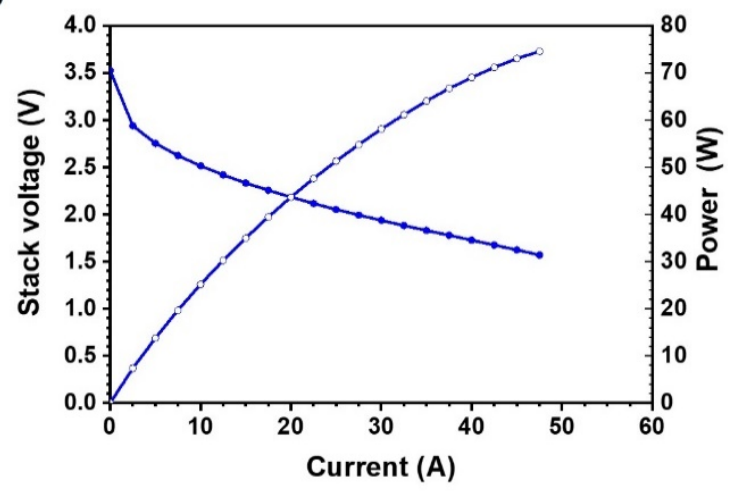

d)

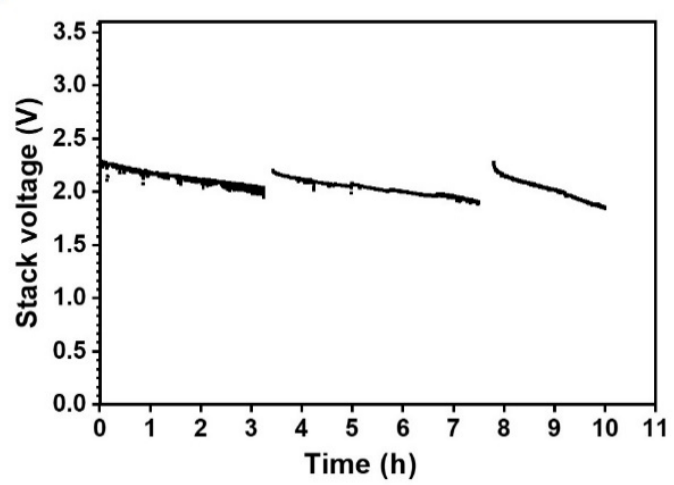

Fig. 5 | Image, performance, and durability of 5-cell stack. a, Illustration of 5-cell DAFC stack. b, Polarization and power density curves of DAFC. $\mathbf{c}$, The comparison of polarization and power density curves of DAFC stack and a $50 \mathrm{~cm}^{2}$ single cell. Test conditions: cell temperature of $90{ }^{\circ} \mathrm{C}$, cathode humidifier temperature of $90{ }^{\circ} \mathrm{C}, 25 \mathrm{~mL} \mathrm{~min}^{-}$ ${ }^{1} 7 \mathrm{M} \mathrm{NH}_{3}$ in $3 \mathrm{M} \mathrm{KOH}$ at $2 \mathrm{bar}_{\mathrm{g},} 0.5 \mathrm{~L} \mathrm{~min}^{-1} \mathrm{O}_{2}$ with a humidifier at $95{ }^{\circ} \mathrm{C}$ and 3 barg. d, short-term stack stability test at $15 \mathrm{~A}$ operating at $90{ }^{\circ} \mathrm{C}$. Anode: $2 \mathrm{mg}_{\mathrm{PGM}} \mathrm{cm}^{-2} \mathrm{PtIr} / \mathrm{C}$ with PiperION PAP-TP-100 ionomer. HEM: PiperION membrane (13 $\mu \mathrm{m}$ thickness, reinforced PAP-TP-85). Cathode: $1.2 \mathrm{mg} \mathrm{cm}^{-2} \mathrm{Co}_{2} \mathrm{MnO}_{4}$ with $20 \mathrm{wt} \%$ PiperION PAPTP-100 ionomer. 
a)

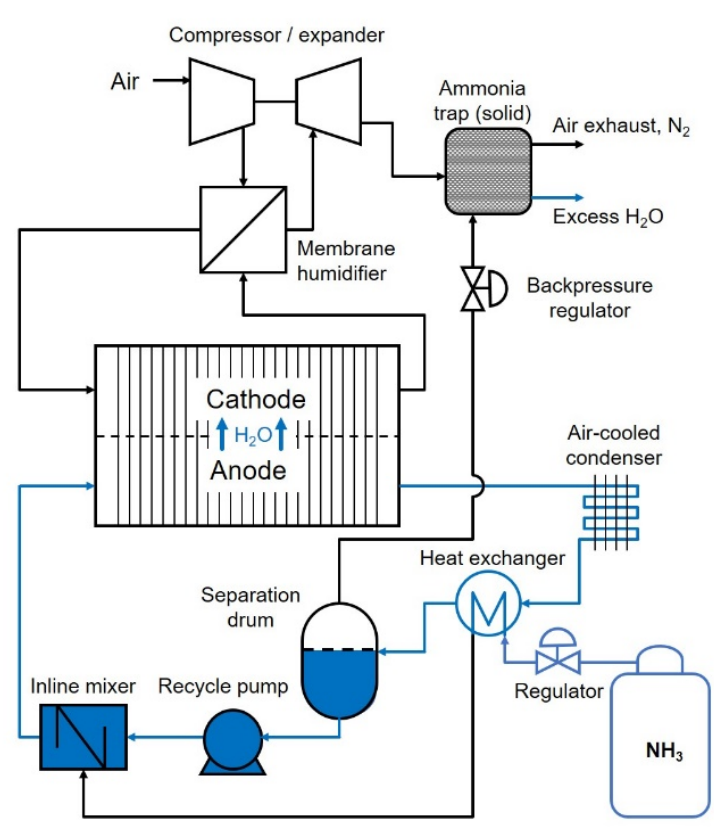

b)

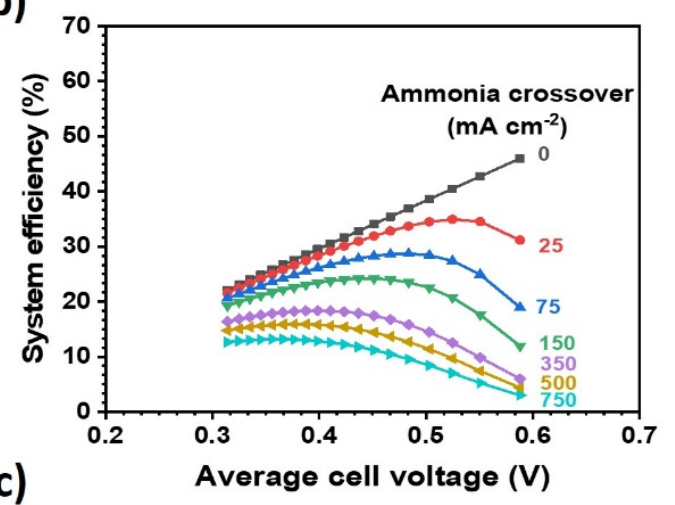

c)

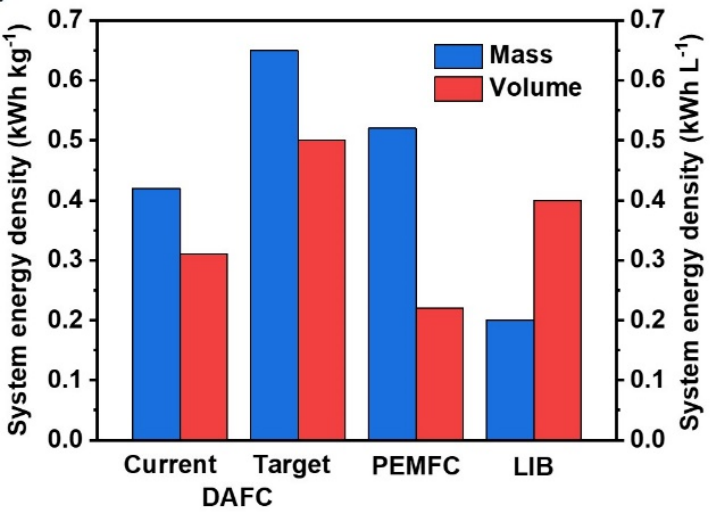

Fig. 6 | Proposed 2 kW, 10 kWh DAFC-based system. a, The proposed process flow diagram of 2kW DAFC-based system. b, System efficiency as a function of ammonia crossover. c, Energy densities of DAFC, PEMFC, and Li Battery-based systems, respectively. 